\title{
Analisis Kemampuan Numerasi dalam Pengembangan Soal Asesmen Kemampuan Minimal pada Siswa Kelas XI SMA untuk Menyelesaikan Permasalahan Science
}

\author{
Anggun Winata, Ifa Seftia Rakhma Widiyanti, Sri Cacik* \\ Universitas PGRI Ronggolawe Tuban \\ *sricacik.mpd@gmail.com
}

\begin{abstract}
Ujian Nasional (UN) will be replaced by Asesmen National (AN) which consists of Asesmen Kompetensi Minimum (AKM), character survey and learning environment survey. AKM includes literacy and numeracy. Numeracy is related to ability to solve science problems. This study aims to describe numeracy abilities students of grade XI senior high school in solving science problems. This type of research is quantitative descriptive and was conducted at MA Darul Ma'wa Plandirejo-Plumpang-Tuban. The research subjects were students of class XI which consisted of 21 students. The research instrument used was a test sheet which included 3 indicators of numeracy skills. The scientific problems used are problems of biology, chemistry and physics. The data collection technique was carried out by survey and test. The results showed that the numeracy skills of grade XI MA Darul Ma'wa Plandirejo-Plumpang-Tuban were still low. It is known that 61.90\% of students get a score below 50. The percentage of wrong answers for the 3 indicators given is $64.76 \% ; 48.57 \%$ and $44.67 \%$. Indicators that get the least correct answer are being able to use various kinds of numbers or symbols related to basic mathematics in solving daily life problems. All research subjects have wrong answer for velocity of the object and concave mirror on that indicator. Based on the research results, further research is needed to determine appropriate learning so that students' numeracy skills have increased.
\end{abstract}

\section{ABSTRAK}

Ujian Nasional (UN) akan digantikan oleh Asesmen Nasional (AN) yang terdiri dari Asesmen Kompetensi Minimum (AKM), survei karakter dan survei lingkungan belajar. AKM meliputi asesmen literasi membaca dan asesmen numerasi. Kemampuan numerasi berhubungan dengan kemampuan menyelesaian masalah-masalah science. Penelitian ini bertujuan untuk mendeskripsikan kemampuan numerasi siswa SMA kelas XI dalam menyelesaikan permasalahan science. Jenis penelitian adalah deskriptif kuantitatif dan dilakukan di MA Darul Ma'wa Plandirejo kecamatan Plumpang kabupaten Tuban. Subjek penelitian adalah siswa kelas XI yang terdiri dari 21 siswa. Instrumen penelitian yang digunakan adalah lembar tes meliputi 3 indikator kemampuan numerasi. Permasalahan science yang digunakan merupakan permasalahan Biologi, Kimia dan Fisika. Teknik pengambilan data dilakukan dengan survei dan tes. Hasil penelitian menunjukkan bahwa kemampuan numerasi siswa kelas XI MA Darul Ma'wa Plandirejo kecamatan Plumpang kabupaten Tuban masih rendah. Hal tersebut diketahui dari 61,90\% siswa mendapatkan nilai di bawah 50. Persentase jawaban salah untuk 3 indikator adalah $64,76 \% ; 48,57 \%$ dan 44,67\%. Indikator yang mendapatkan jawaban benar paling sedikit yaitu mampu menggunakan berbagai macam angka atau simbol yang terkait dengan matematika dasar dalam menyelesaikan masalah kehidupan sehari-hari. Semua subjek penelitian memberikan jawaban salah untuk kecepatan gerak benda dan cermin cekung di indikator tersebut. Berdasarkan hasil penelitian, diperlukan penelitian lanjutan untuk mengetahui pembelajaran yang sesuai sehingga kemampuan numerasi siswa mengalami peningkatan.

Kata Kunci: AKM numerasi; permasalahan science

Submitted May 15, 2021 | Revised Jun 12, 2021 | Accepted Jun 16, 2021

\section{Pendahuluan}

Asesmen Kompetensi Minimum (AKM) merupakan salah satu evaluasi pengganti Ujian Nasional (UN) yang dilakukan pemerintah setiap tahunnya. Sejak tahun 2003, nilai UN dijadikan sebagai penentu kelulusan siswa dan standar untuk melanjutkan ke jenjang pendidikan yang lebih tinggi, namun pada tahun 2015 nilai UN tidak lagi menjadi penentu kelulusan akan tetapi UN tetap menjadi hal yang menakutkan, menegangkan dan menguras tenaga pelaku di lapangan (Aisah, 2021). Saat ini, pemerintah sudah menetapkan bahwa UN ditiadakan dan diadakan AKM. Selain AKM, survei karakter merupakan 
salah satu evaluasi dalam kebijakan merdeka belajar menurut Menteri Pendidikan dan Kebudayaan diawal kepemimpinannya sekitar bulan Oktober tahun 2019. Kebijakan merdeka belajar terdiri atas 4 hal sebagai berikut: (1) Ujian Sekolah Berstandar Nasional (USBN) ditiadakan dan program ini dikembalikan kepada kebijakan sekolah, (2) Ujian Nasional (UN) diganti dengan Asesmen Kompetensi Minimum (AKM) dan survei karakter, (3) 13 komponen yang terdapat dalam Rencana Pelaksanaan Pembelajaran (RPP) diganti menjadi 3 komponen, (4) Peraturan Penerimaan Siswa Baru (PPDB) yang berorientasi pada proporsional (Kusumaryono, 2020).

Kebijakan nomor 2, adanya reformasi terhadap UN yang diganti dengan AKM dibutuhkan untuk dapat mendorong peningkatan kualitas pembelajaran di Indonesia. Selama ini, kemampuan belajar siswa di Indonesia berdasarkan hasil Programme for International Student Assessment (PISA) menunjukkan hasil yang masih rendah pada pendidikan dasar dan menengah. Dibanding negara-negara lainnya di Asia, Indonesia tergolong dalam urutan terbawah. Hasil ini didasarkan pada hasil survei yang dilakukan oleh PISA tahun 2018. Hasil survei PISA menunjukkan bahwa siswa di Indonesia memiliki kompetensi literasi membaca sekitar 70\% dan termasuk masih pada level bawah (OECD, 2018). Selain itu, keterampilan matematika dan sains siswa di Indonesia berturut-turut sekitar $71 \%$ dan $60 \%$ yang juga masih pada level bawah (OECD, 2018). Hasil survei PISA di Indonesia tidak memberikan hasil kenaikan yang signifikan dalam kurun waktu 10-15 tahun terakhir. Hasil ini membuat Indonesia menjadi salah satu negara yang hasilnya konsisten terendah pada peringkat hasil survei PISA. Hasil kemampuan siswa yang termasuk terendah dibandingkan negara-negara lain tersebut menjadikan Indonesia perlu melakukan pemetaan mutu pendidikan secara menyeluruh dalam peningkatan kualitas pembelajaran. Berdasarkan hal tersebut, maka Asesmen Nasional (AN) resmi diterapkan oleh Kementerian Pendidikan dan Kebudayaan (Kemendikbud) pada tahun 2021 dan sudah tidak diperlakukan lagi Ujian Nasional (UN). Kebijakan Kemendikbud ini ditetapkan berdasarkan hasil koordinasi Kemendikbud bersama sejumlah dinas dan lembaga yang terkait.

Asesmen Ketuntasan Minimum (AKM) merupakan bagian dari AN. Pelaksanaan dari AKM bersifat adaptif yang artinya setiap peserta didik mengerjakan soal sesuai dengan kemampuannya (Maryuliana, 2016). AKM mengukur kompetensi mendasar yang perlu dipelajari oleh semua siswa tanpa membedakan peminatannya. Oleh karena itu, seluruh siswa akan mendapat soal yang dapat mengukur kompetensi yang sama. AKM yang ditetapkan oleh pemerintah merupakan salah satu bagian dari target pemeritah untuk menyiapkan siswa dalam menghadapi abad 21, yaitu memiliki kecakapan Critical thinking, Creativity, Communication skills and Collaboratively (Andiani, 2020). AKM terdiri dari kemampuan literasi dan numerasi. Kedua kemampuan ini penting karena kemampuan literasi dan numerasi merupakan kompetensi mendasar yang dibutuhkan oleh siswa terlepas dari profesi dan citacitanya dimasa depan. Selain itu, kemampuan literasi dan numerasi juga berhubungan dengan pengambilan keputusan yang bijak dalam kehidupan siswa itu sendiri.

Asesmen kemampuan numerasi dilakukan untuk mengukur kemampuan siswa dalam menggunakan konsep dan atau prosedur serta fakta dan atau alat matematika (Maryuliana, 2016). Pengukuran kemampuan numerasi diberikan dalam penyelesaian masalah dalam berbagai jenis konteks yang sesuai. Asesmen yang dibuat masih dalam tahap pengembangan sehingga perlu dilakukan uji coba untuk mengkaji perspektif secara teoritis mengenai rancangan soal AKM numerasi. Asesmen kemampuan numerasi yang dikembangkan bertujuan untuk mengukur kemampuan berpikir siswa dalam menggunakan konsep, prosedur, fakta, alat matematika untuk menyelesaikan masalah sehari-hari yang relevan pada berbagai konteks. Beberapa hal yang diujikan dalam asesmen kemampuan numerasi adalah bilangan, geometri dan pengukuran, data dan ketidakpastian, serta aljabar.

Asesmen kemampuan numerasi dikembangkan untuk mengetahui kemampuan numerasi dari siswa yang berhubungan dengan kemampuan matematika. Selain itu, kemampuan numerasi juga berhubungan dengan banyak aspek termasuk science. Science merupakan bidang kajian yang berkaitan dengan peristiwa alam yang melibatkan penyelidikan, penelitian dan pengukuran untuk memperjelas 
sebab akibat dari fenomena alam yang membutuhkan kemampuan numerasi. Kegiatan pada bidang science digunakan untuk menunjukkan bukti yang dibutuhkan dalam menjawab pertanyaan ilmiah dan permasalahan di kehidupan manusia (Yuanita \& Kurnia, 2017). Jawaban atas permasalahan ilmiah memerlukan kemampuan numerasi, yaitu memahami dan menggunakan matematika untuk menyelesaikan masalah atau menjelaskan suatu informasi. Sejalan dengan itu, Pusmenjar Kemdikbud, (2020) menyatakan bahwa proses kognitif dan konteks menjadi dasar asesmen kemampuan numerasi. Berdasarkan proses kognitif, asesmen kemampuan numerasi berkaitan dengan proses pemahaman konsep, selanjutnya pemahaman konsep tersebut digunakan untuk bernalar dalam menyelesaikan masalah. Berdasarkan konteks, asesmen kemampuan numerasi berkaitan dengan konteks personal, sosial budaya dan saintifik.

Menurut Cockroft dalam Goos, at all (2011), kemampuan numerasi merupakan sebuah keahlian dalam menyelesaikan masalah secara praktis dengan menggunakan angka. Kemampuan numerasi merupakan kemampuan menerapkan konsep bilangan, keterampilan operasi hitung dan kemampuan menjelaskan suatu informasi yang terdapat di sekitar kita (Han, dkk. (2017). Secara ringkas kemampuan numerasi disebut sebagai kemampuan dalam memahami dan menggunakan matematika pada berbagai konteks dengan tujuan untuk dapat menyelesaikan masalah dan mampu menjelaskan suatu informasi kepada orang lain menggunakan matematika. Merujuk pada Han, dkk. (2017), indikator kemampuan numerasi adalah (1) menggunakan berbagai macam angka dan simbol yang terkait dengan matematika dasar untuk memecahkan masalah dalam berbagai macam konteks kehidupan sehari-hari, (2) menganalisis informasi yang ditampilkan dalam berbagai bentuk (grafik, tabel, bagan, diagram dan lain sebagainya) (3) menafsirkan hasil analisis tersebut untuk memprediksi dan mengambil keputusan.

Kemampuan numerasi dalam AN selain literasi dapat diterapkan pada beberapa jenjang di sekolah. Pemilihan jenjang kelas V, VIII dan XI sebagai peserta AN dimaksudkan karena kelas tersebut dapat merasakan perbaikan pembelajaran ketika mereka masih berada di sekolah tersebut. Pertimbangan lain yaitu siswa jenjang kelas V, VIII dan XI telah mengalami proses pembelajaran di sekolahnya, sehingga sekolah dapat dikatakan telah berkontribusi pada hasil belajar yang diukur dalam AN. Berikut ini beberapa penelitian sebelumnya terkait kemampuan numerasi: Wicaksana, dkk. (2017) menyatakan bahwa kemampuan numerasi kelas XI IPA pada pembelajaran berbasis proyek dengan berbantuan schoology berkategori baik. Pangesti (2018) menyampaikan bahwa kemampuan numerasi dapat ditumbuhkembangkan dengan pengetahuan matematika yang dipelajari sesuai kurikulum, namun guru harus mendesain materi matematika tersebut salah satunya dengan membuat soal HOTS. Maulidina (2019) menyatakan bahwa siswa kelas 2 SD yang memiliki kemampuan tinggi mampu dan benar dalam menggunakan berbagai macam angka atau simbol yang terkait dengan matematika dasar untuk memecahkan masalah dalam berbagai macam konteks kehidupan sehari-hari, mampu menganalisis informasi yang ditampilkan dalam berbagai bentuk (grafik, tabel, bagan, diagram dan lain sebagainya) dan mampu menafsirkan hasil analisis tersebut untuk memprediksi dan mengambil keputusan dengan baik. Hartatik (2020) menyatakan bahwa kemampuan terendah mahasiswa PPG SD dalam jaringan tahun 2019 dalam menyelesaikan masalah matematika adalah menggunakan simbol atau angka terkait matematika dalam menyelesaikan masalah sehari-hari, hal tersebut dikarenakan banyaknya kesalahan dalam penulisan angka dan simbol untuk menyelesaikan masalah.

Subjek penelitian ini adalah siswa kelas XI MA Darul Ma'wa Plandirejo kecamatan Plumpang kabupaten Tuban. Pemilihan siswa kelas XI MA sebagai subjek penelitian, menitikberatkan pada pengembangan kognitif anak, yaitu taraf berfikir operasional formal atau berpikir abstrak berdasarkan teori perkembangan kognitif Piaget. Selain itu, berdasarkan survei PISA, kemampuan numerasi pada jenjang pendidikan dasar dan menengah masih rendah. Oleh karena itu, perlu dilakukan analisis kemampuan numerasi dalam pengembangan soal AKM pada siswa kelas XI MA dalam menyelesaikan permasalahan science. Melalui analisis tersebut akan diperoleh gambaran profil dari kemampuan numerasi di MA Darul Ma'wa Plandirejo kecamatan Plumpang Kabupaten Tuban yang selanjutnya 
dapat dilakukan upaya berupa pendekatan pembelajaran, strategi pembelajaran atau model pembelajaran yang sesuai.

\section{Metode Penelitian}

Penelitian yang telah dilakukan merupakan penelitian deskriptif kuantitatif di mana bertujuan untuk menunjukkan atau memberikan gambaran terkait kemampuan numerasi siswa kelas XI untuk menyelesaian masalah science. Penelitian deskriptif kuantitatif adalah jenis penelitian yang digunakan untuk menganalisis data dengan cara mendeskripsikan atau menggambarkan data yang telah diperoleh. Penelitian ini dilakukan di salah satu Madrasah Aliyah (MA) swasta yang ada di kabupaten Tuban, yaitu MA Darul Ma'wa Plandirejo kecamatan Plumpang. Pelaksanaan penelitian pada tanggal 03-04 Mei 2021. Target yang ingin diperoleh oleh peneliti setelah melakukan penelitian ini adalah kemampuan numerasi dari peserta didik di MA Darul Ma'wa Plandirejo kecamatan Plumpang kabupaten Tuban dapat dideskripsikan dengan jelas sehingga dapat menunjukkan kesiapan peserta didik untuk menghadapi AKM. Apabila peserta didik masih kurang dalam menghadapi AKM, maka guru dapat berupaya untuk meningkatkan kualitas pembelajarannya khususnya guru pengampu mata pelajaran Biologi, Kimia dan Fisika sesuai soal AKM numerasi yang diujicobakan oleh peneliti.

Subjek penelitian adalah siswa kelas XI MA Darul Ma'wa Plandirejo kecamatan Plumpang kabupaten Tuban yang terdiri dari 21 siswa. Pemilihan kelas XI sebagai subjek penelitian disesuaikan dengan pelaksanaan AKM yang akan dilakukan di jenjang SMA kelas XI. Peneliti memilih MA Darul Ma'wa kecamatan Plumpang kabupaten Tuban karena MA tersebut adalah salah satu MA yang ada di pinggiran kota sehingga diharapkan hasil penelitian yang diperoleh dapat menunjukkan kesiapan siswa di daerah pinggiran kota dalam menghadapi AKM nantinya.

Prosedur penelitian yang dilakukan adalah survei dan pemberian tes tulis berupa soal AKM numerasi. Pada tahap survei, peneliti melakukan wawancara terstruktur kepada beberapa pendidik dan peserta didik. Instrumen yang digunakan pada tahap pemberian tes berupa soal-soal numerasi yang terdiri dari 15 item soal, yaitu 5 soal numerasi Biologi, 5 soal numerasi Kimia dan 5 soal numerasi Fisika. 15 soal AKM numerasi tersebut mencakup 3 indikator, yaitu:

Tabel 1. Indikator Numerasi

\begin{tabular}{cl}
\hline No. & \multicolumn{1}{c}{ Indikator } \\
\hline 1 & $\begin{array}{l}\text { Mampu menggunakan berbagai macam angka atau simbol yang terkait dengan matematika dasar } \\
\text { dalam menyelesaikan masalah kehidupan sehari-hari. }\end{array}$ \\
2 & $\begin{array}{l}\text { Mampu menganalisis informasi yang ditampilkan dalam berbagai bentuk (grafik, tabel, bagan, } \\
\text { diagram dan lain sebagainya). }\end{array}$ \\
3 & Menafsirkan hasil analisis tersebut untuk memprediksi dan mengambil keputusan. \\
\hline Sumber: Han, dkk (2017)
\end{tabular}

Masing-masing indikator tersebut terdiri dari 5 soal, apabila semua subjek penelitian menjawab dengan benar, maka akan diperoleh 105 jawaban benar untuk setiap indikator. Analisis data yang dilakukan oleh peneliti terkait kemampuan peserta didik untuk memberikan jawaban benar pada ketiga indikator tersebut adalah mendeskripsikan kesiapan peserta didik untuk masing-masing indikator.

Skor yang diberikan untuk 15 soal AKM numerasi terdiri dari skor 1, 2 dan 3 disesuaikan dengan tingkat kesulitan soal. Sehingga skor maksimal yang diperoleh subjek penelitian adalah 31. Nilai yang diperoleh subjek penelitian dihitung dengan rumus persentase.

\section{Hasil dan Pembahasan}

Berikut adalah hasil analisis kemampuan numerasi dari 21 siswa yang mengerjakan 15 soal numerasi dalam permasalahan dalam bidang science yang terdiri dari 5 soal kimia, 5 soal fisika, dan 5 soal biologi. Hasil penilaian dari 21 siswa dapat dilihat pada Gambar 1. 


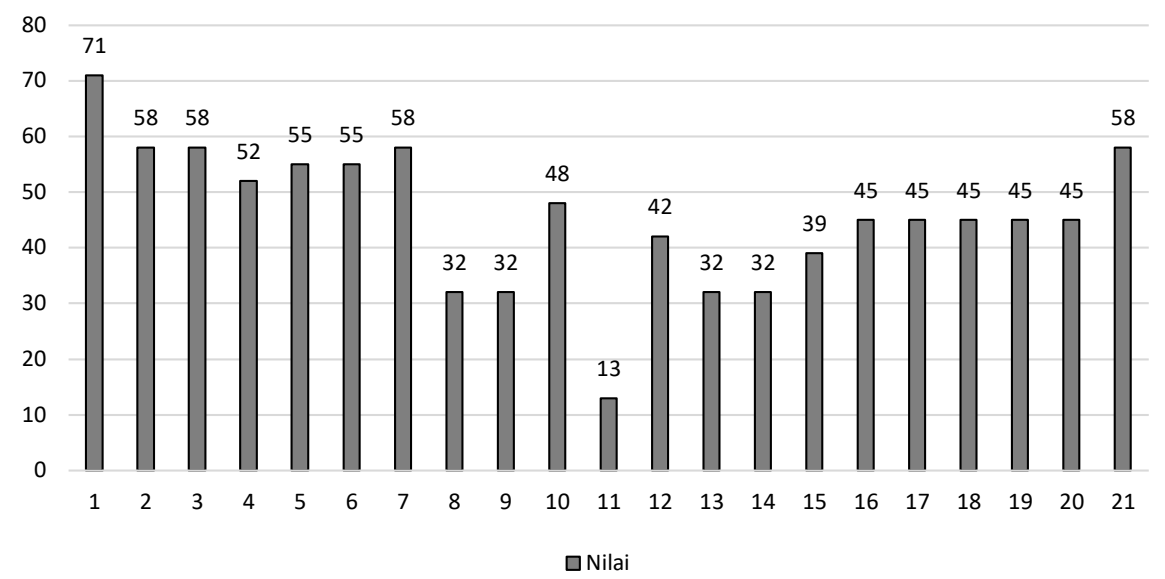

Gambar 1. Nilai Kemampuan Numerasi Siswa

Dari 21 siswa yang melakukan tes kemampuan numerasi sekitar 61,90\% siswa masih memiliki nilai dibawah 50. Hal ini menunjukkan bahwa lebih dari separuh jumlah siswa memiliki kemampuan numerasi yang termasuk dalam kriteria rendah. Kemampuan siswa dengan kriteria rendah tersebut mengindikasikan bahwa siswa masih lemah dalam menggunakan angka, simbol atau bentuk penyajian secara matematika dalam memecahkan masalah, memprediksi dan mengambil keputusan.

Secara lebih rinci kemampuan numerasi dapat diidentifikasi dari 3 indikator kemampuan numerasi yang mengadopsi dari Han, dkk (2017) yaitu (1) Menggunakan berbagai macam angka dan simbol yang terkait dengan matematika dasar untuk memecahkan masalah dalam berbagai macam konteks kehidupan sehari-hari, (2) Menganalisis informasi yang ditampilkan dalam berbagai bentuk (grafik, tabel, bagan, diagram dan lain sebagainya), (3) Menafsirkan hasil analisis tersebut untuk memprediksi dan mengambil keputusan. Hasil ketiga indikator kemampuan numerasi dapat dilihat pada Tabel 2 berikut.

Tabel 2. Pemetaan untuk Masing-masing Indikator

\begin{tabular}{llcc}
\hline & \multicolumn{1}{c}{ Indikator } & \multicolumn{2}{c}{ Jumlah Jawaban } \\
\cline { 2 - 3 } & & Benar & Salah \\
\hline 1. & $\begin{array}{l}\text { Mampu menggunakan berbagai macam angka atau simbol yang terkait dengan } \\
\text { matematika dasar dalam menyelesaikan masalah kehidupan sehari-hari. }\end{array}$ & 37 \\
2. $\begin{array}{l}\text { Mampu menganalisis informasi yang ditampilkan dalam berbagai bentuk (grafik, } \\
\text { tabel, bagan, diagram dan lain sebagainya). }\end{array}$ & 56 & 49 \\
3. $\begin{array}{l}\text { Menafsirkan hasil analisis tersebut untuk memprediksi dan mengambil } \\
\text { keputusan. }\end{array}$ & 54 & 51 \\
\hline
\end{tabular}

\section{Keterangan:}

Jumlah soal untuk indikator $1=5$ soal Jumlah soal untuk indikator $2=5$ soal Jumlah soal untuk indikator $3=5$ soal Jumlah siswa (subjek) = 21 siswa

Berdasarkan hasil setiap indikator kemampuan numerasi, diperoleh bahwa indikator 1 banyak yang masih salah dalam menjawab soal yang berhubungan dengan kemampuan dalam menggunakan berbagai macam angka atau simbol yang terkait dengan matematika dasar dalam menyelesaikan masalah kehidupan sehari-hari yaitu sekitar $64,76 \%$. Selanjutnya disusul oleh indikator ke-3 yaitu kemampuan dalam menafsirkan hasil analisis tersebut untuk memprediksi dan mengambil keputusan sebesar 48,57\%. Dan terakhir yang memperoleh jawaban salah paling sedikit adalah indikator ke-2 tentang kemampuan dalam menganalisis informasi yang ditampilkan dalam berbagai bentuk (grafik, tabel, bagan, diagram dan lain sebagainya), yaitu 44,67\%. 
Berdasarkan ketiga indikator tersebut dapat disimpulkan bahwa siswa kesulitan dalam menggunakan berbagai macam angka atau simbol yang terkait dengan matematika dasar untuk menyelesaikan masalah kehidupan sehari-hari (indikator 1) dibandingkan dengan menafsirkan hasil analisis untuk memprediksi dan mengambil keputusan (indikator 3) atau menganalisis informasi grafik, tabel, bagan, diagram dan lain sebagainya (indikator 2). Kemampuan menggunakan berbagai macam angka atau simbol yang terkait dengan matematika dasar dalam menyelesaikan masalah kehidupan sehari-hari termasuk kedalam level PISA yang paling rendah yaitu level 1-3, sedangkan menganalisis informasi dan menafsirkan hasil analisis tergolong level 4-6 (OECD, 2014).

Kemampuan menganalisis informasi yang ditampilkan dalam bentuk grafik, tabel, bagan, diagram dll. memperoleh hasil yang paling tinggi dibandingkan dengan indikator lainnya. Hal ini disebabkan karena representasi berupa grafik, tabel, bagan, diagram dll. lebih mudah dipahami dibandingkan katakata (Hartatik \& Nurfiah, 2020). Pada indikator 1 dan 3 memperoleh hasil yang lebih rendah dibandingkan dengan indikator 2 karena dua indikator tersebut lebih tinggi levelnya dibandingkan indikator 2. Setelah siswa mampu untuk menganalisis informasi dengan baik, siswa baru dapat menafsirkan hasil analisis untuk memprediksi dan mengambil keputusan serta dapat menyelesaikan masalah kehidupan sehari-hari. Kemampuan tersebut termasuk dalam kemampuan metakognitif.

Hasil kemampuan numerasi setiap indikator secara terperinci dapat dilihat dari Gambar 2-4.

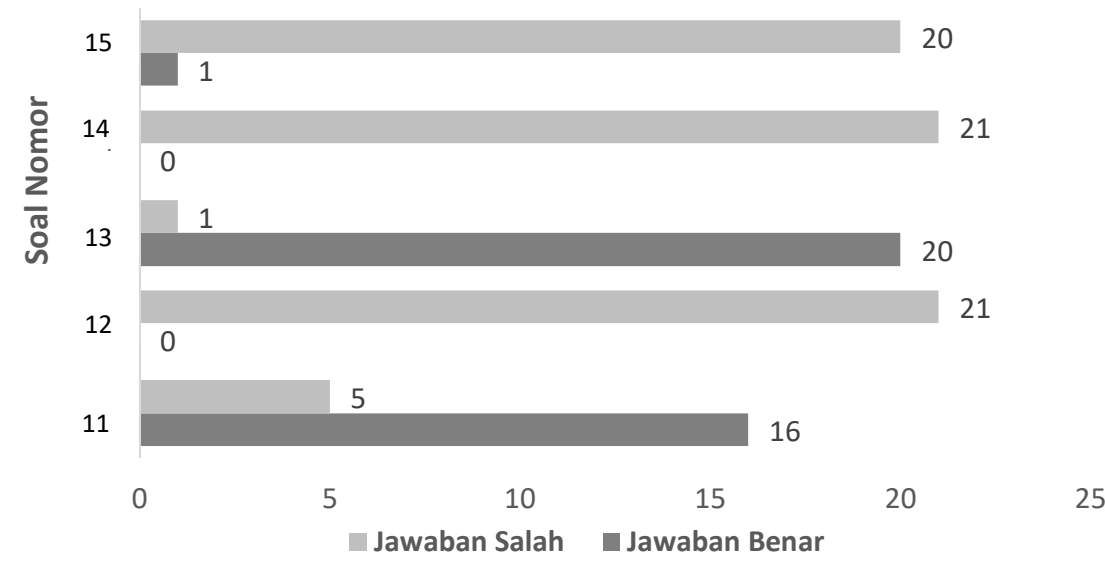

Gambar 2. Profil Jawaban Benar dan Salah Soal Numerasi Pada Indikator-1

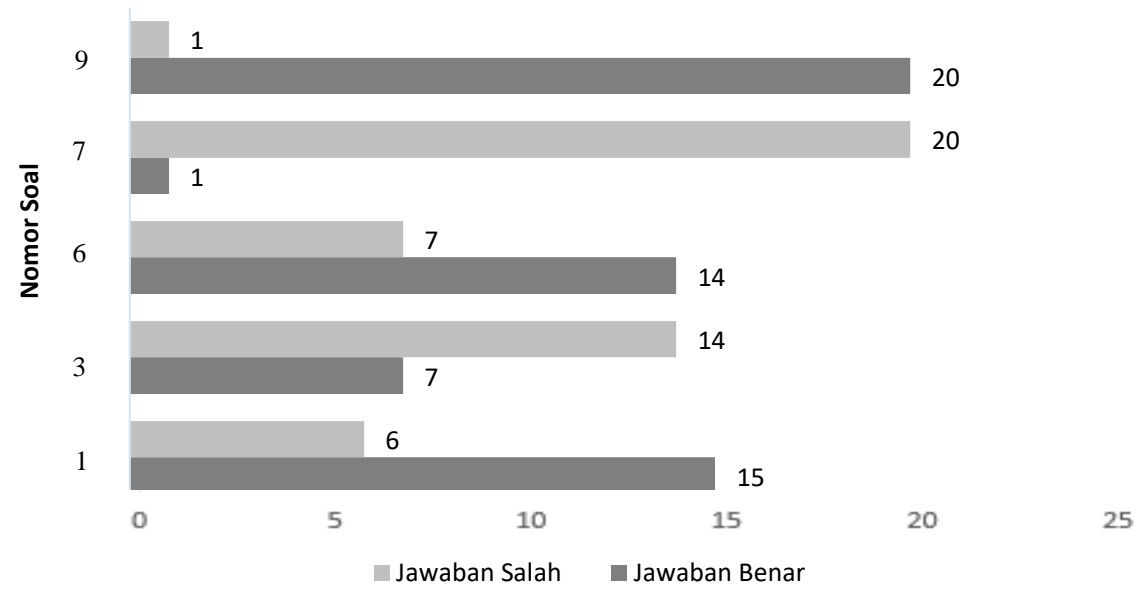

Gambar 3. Profil Jawaban Benar dan Salah Soal Numerasi Pada Indikator-2 


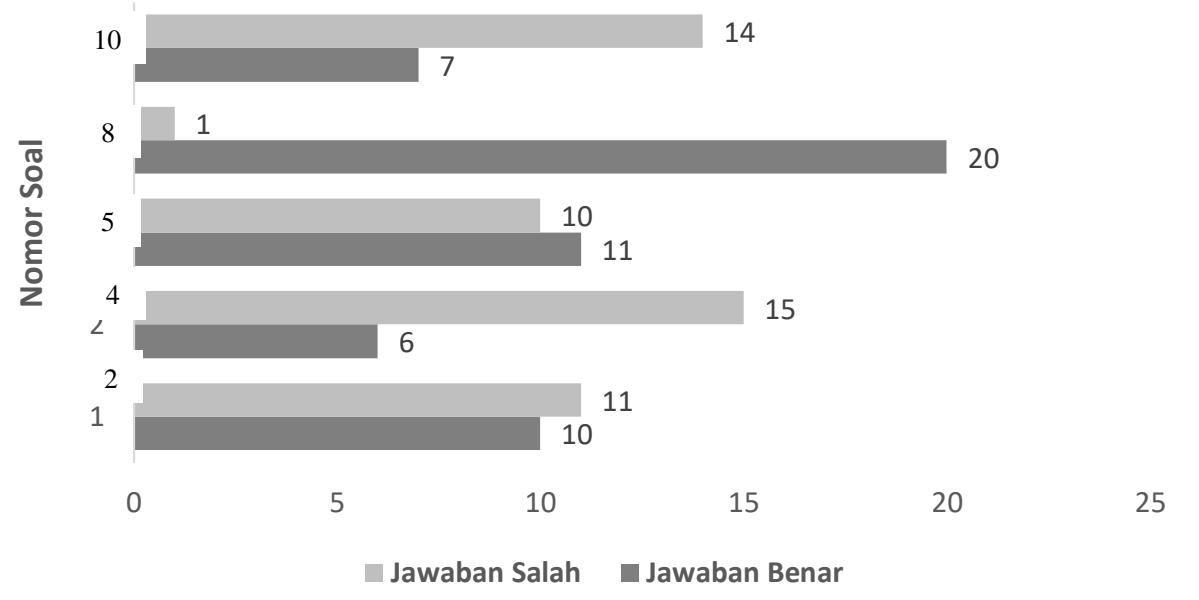

Gambar 4. Profil Jawaban Benar dan Salah Soal Numerasi Pada Indikator-3

Berdasarkan data profil jawaban siswa pada masing-masing indikator. Indikator-2 memberikan hasil nilai numerasi tertinggi dari ketiga indikator yang dianalisis. Pada Indikator-2, siswa banyak yang menjawab salah pada soal nomor 7 dan siswa banyak menjawab benar pada soal nomor 9. Soal nomor 7 dan 9 dapat dilihat pada Gambar 5.

7. Pagi ini Sofia tergesa-gesa menuju kantornya karena waktu sudah menunjukkan pukul 07.45 WIB. Sofia harus mengejar jam 08.00 WIB untuk sampai ke kantornya. Saking terburu-burunya, Sofia tidak sempat sarapan seperti biasa. Sofia hanya memakan kue muffin yang dia beli kemarin. Langkahnya terburu-buru menuju ke kantor. Berdasarkan wacana berjudul "Yuk Kenalan Sama Kalori Junk Food!”, berapa kalori yang sudah terbakar ketika Sofia sampai kantor? Jelaskan! Jawab:

9. Ibu Wati berusia 42 tahun, berdasarkan wacana berjudul "Apakah Detak Jantung Anda Normal?", jumlah denyut jantung yang baik untuk ibu Wati adalah ....
A. $62 \mathrm{bpm}$
B. $65 \mathrm{bpm}$
C. $70 \mathrm{bpm}$
D. $75 \mathrm{bpm}$
E. $82 \mathrm{bpm}$

Gambar 5. Soal Nomor 7 dan 9 pada Indikator-2

Pada soal nomor 7, siswa banyak yang menjawab salah karena selain tipe soal berupa uraian terbuka, pada soal nomor 7 mengharuskan siswa paham tabel kalori Junk Food yang diberikan dan selanjutnya siswa melakukan analisis dan melakukan penerapan tabel kalori Junk Food dalam rasa lapar. Pada nomor 9 banyak siswa yang jawab benar karena tipe soalnya berupa pilihan ganda yang mudah dipahami dan bisa diperkirakan jawabannya. Selain itu, table pada soal nomor 9 yang diberikan untuk dianalisis mudah dipahami siswa. 
Bacalah wacana berjudul "Siklus Krebs" berikut ini!

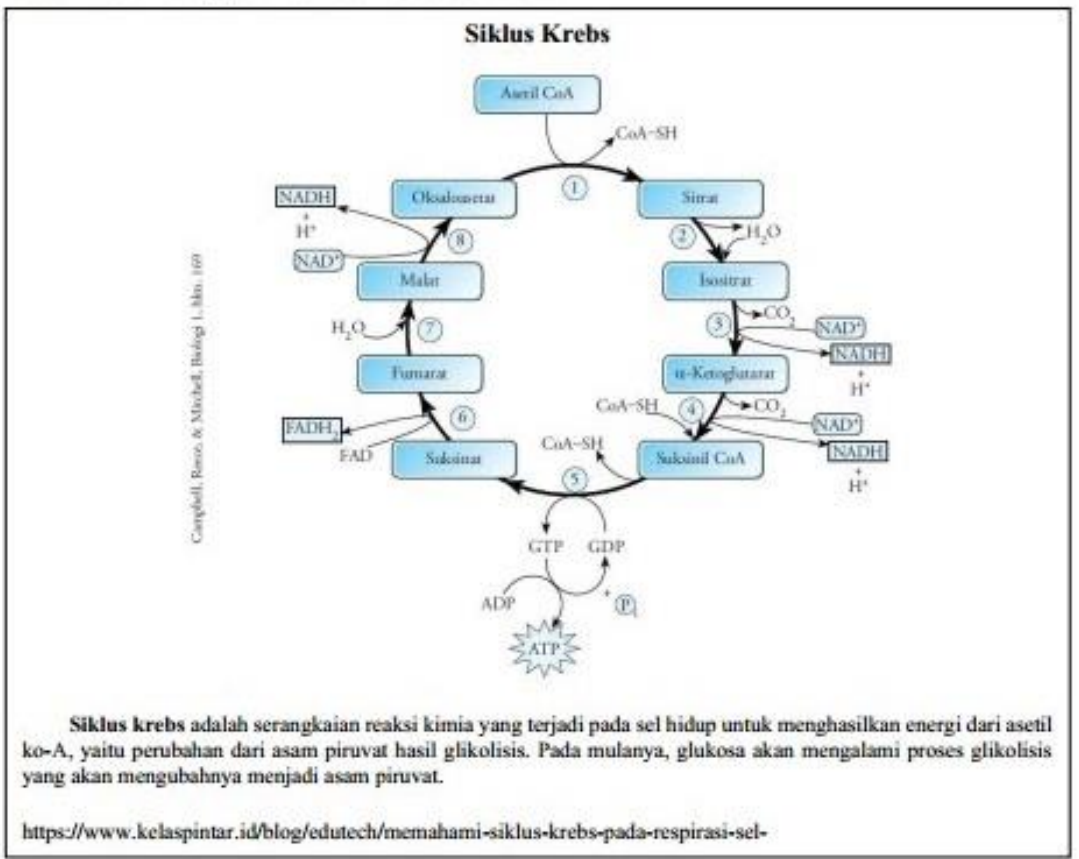

4. Berdasarkan wacana berjudul "Siklus Krebs", tentukan benar atau salah pernyataan berikut: Enzim isositrat mengatalis reaksi dekarboksilasi oksidatif isositrat menjadi a-koteglutarat dan karbondioksida, lalu terjadi pelepasan $\mathrm{H}^{+}$untuk memproduksi NAD ${ }^{+}$.

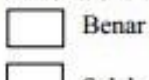

8. Berdasarkan Tabed Detak Jantung uatuk Laki-laki pada wacama berjudul "Apakah Detak Jantang Anda Normal?", tentakan diagram berikut yang benar!

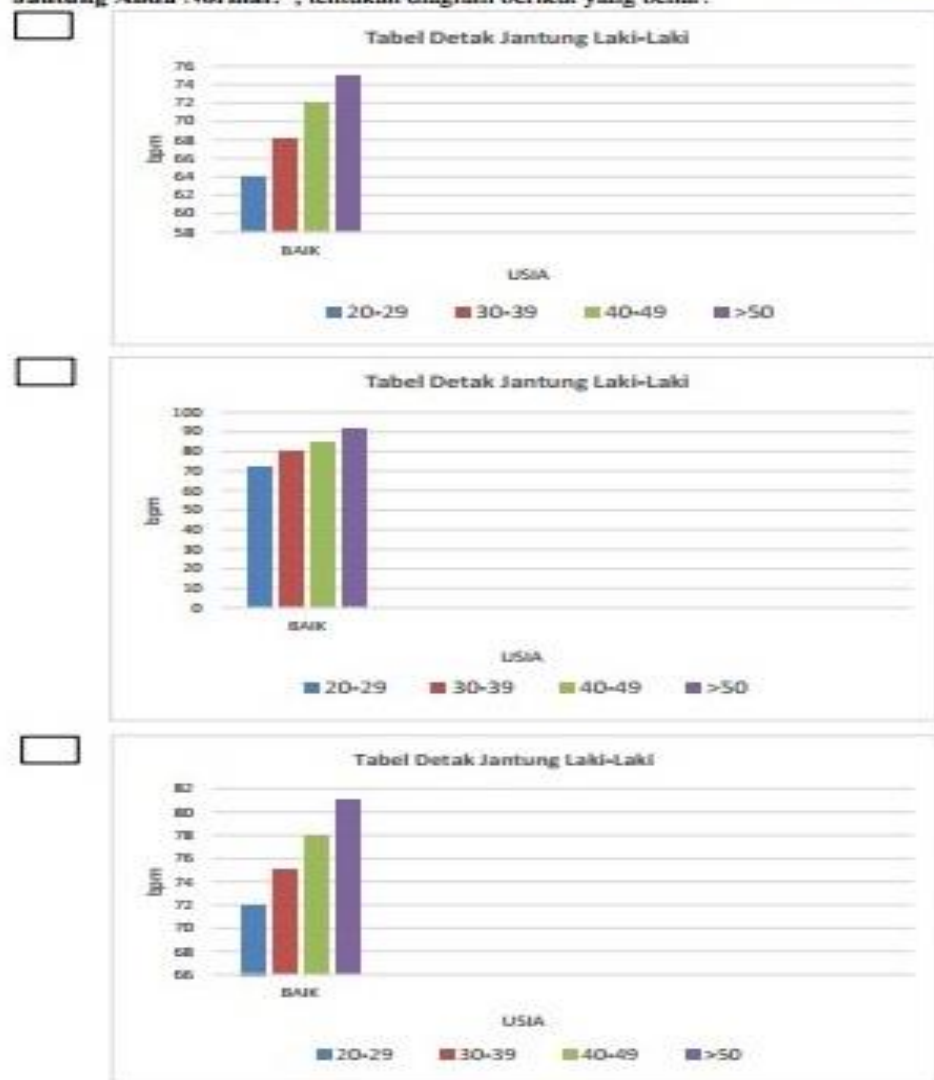

Gambar 6. Soal Nomor 4 dan 8 pada Indikator-3 
Pada indikator-3, siswa banyak yang menjawab salah pada soal nomor 4 dan banyak jawaban siswa menjawab benar pada soal nomor 8. Soal nomor 4 dan 8 dapat dilihat pada Gambar 6. Pada soal nomor 4, untuk menafsirkan hasil analisis dari pernyataan, memprediksi dan mengambil keputusan perlu memahami dan mengingat siklus Krebs yang berhubungan dengan pengetahuan awal siswa. Jika hal tersebut tidak dimiliki oleh siswa maka siswa tidak dapat memberikan jawaban benar. Pada nomor 8 , siswa menafsirkan berdasarkan analisis Tabel detak jantung normal dan menyimpulkan dalam bentuk grafik, hal tersebut lebih mudah karena tidak diperlukan pengetahuan awal tentang detak jantung.

Pada indikator-1, banyak siswa menjawab salah sehingga kemampuan numerasi siswa pada indikator-1 memperoleh hasil paling rendah dibandingkan ketiga indikator yang dianalisis. Pada indikator-1, banyak siswa menjawab salah untuk soal nomor 12 dan 14 sedangkan pada soal nomor 13 banyak siswa menjawab benar. Gambar 7 menunjukkan soal nomor 12 dan 13. Sedangkan Gambar 8 menunjukkan soal nomor 14 .

12. Bacalah wacana berjudul "Ketipung" berikut ini! Supaya pelayangan bunyi yang dihasilkan dua Ketipung tersebut sama dengan 2 kali pelayangan bunyi yang telah dihasilkan saat pemukulan atau penabuhan yang pertama, maka frekuensi bunyi yang harus dihasilkan oleh Ketipung A dan $\mathrm{B}$ harus diubah. Pilihlah pernyataan yang benar!

Betipung

Salah satu alat musik tradisional Jawa Timur adalah Ketipung. Bentuknya menyerupai Gendang tetap ukurannya lebih kecil. Beberapa orang sering kali mengatakan bahwva Ketipung adalah Gendang dangdut. Bunyi yang dihasilkan oleh Ketipung saat dimainkan sangat memikat hati pendengarnya.

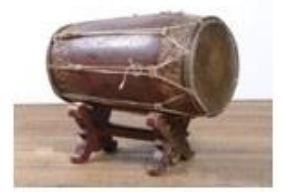

Salah satu fenomena yang terjadi jika terdapat dua sumber bunyi menimbulkan bunyi secara bersamaan adalah terjadinya pelayangan bunyi. Pada suatu permainan musik, dua pemain Ketipung memukul atau menabuh dua buah ketipung (Ketipung A dan B) secara bersamaan. Frekuensi yang dihasilkan oleh Ketipung A adalah $200 \mathrm{~Hz}$ buah ketipung (Ketipung A dan B) secara bersamaan. Frekuens
dan frekuensi yang dihasilkan oleh ketipung $B$ adalah $300 \mathrm{~Hz}$.

Frekuensi Ketipung A adalah 4 kali semula dan frekuensi Ketipung B adalah 2 kali semula.

Frekuensi Ketipung A adalah 2 kali semula dan frekuensi Ketipung B adalah 3 kali semula.

Frekuensi Ketipung A adalah 0,5 kali semula dan frekuensi Ketipung B adalah tetap.

Frekuensi Ketipung A adalah 3 kali semula dan frekuensi Ketipung B adalah tetap.

Frekuensi Ketipung A adalah 2 kali semula dan frekuensi Ketipung B adalah 0,5 kali semula.

13. Bacalah wacana berjudul "Jangka Sorong" berikut ini!

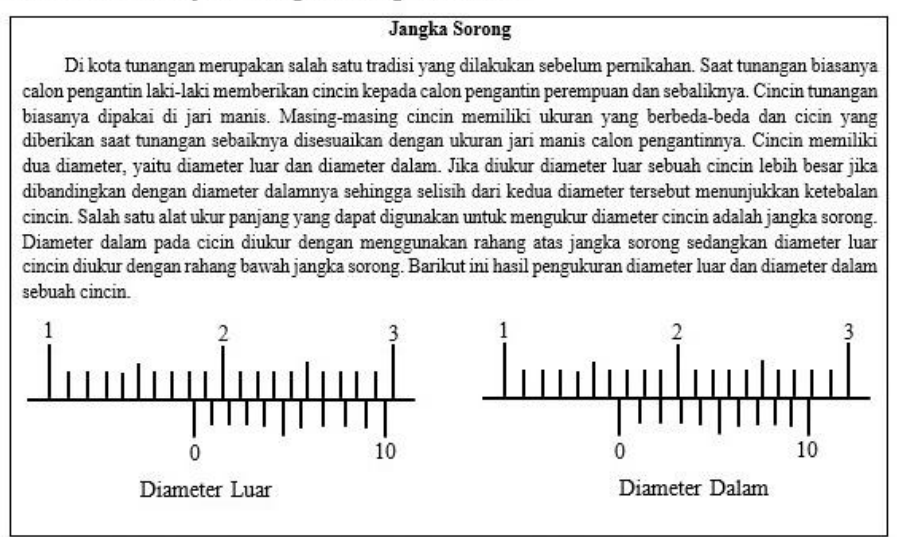

Berdasarkan hasil pengukuran yang ditunjukkan oleh gambar pada wacana berjudul "Jangka Sorong" di atas, Berapa ketebalan cincin tersebut?

A. $0,15 \mathrm{~cm}$

B. $0,17 \mathrm{~cm}$

C. $1,12 \mathrm{~cm}$

D. $0,20 \mathrm{~cm}$

E. $1,10 \mathrm{~cm}$

Gambar 7. Soal Nomor 12 dan 13 pada Indikator-1 
14. Bacalah wacana berjudul "Balap Sepeda Motor" berikut ini!

Balap Sepeda Motor
Pada suatu balap sepeda motor terdapat sepuluh peserta yang mengikuti acara tersebut. Masing-masing
peserta menggunakan sepeda motor dan dikasih penanda berupa huruf A-J. Panitia mencatat waktu yang
diperlukan oleh sepuluh peserta tersebut untuk menempuh jarak $150 \mathrm{~km}$ pada sebuah tabel. Berikut ini data waktu
tempuh sepuluh peserta lomba:
\begin{tabular}{|c|c|}
\hline Sepeda Motor & Waktu Tempuh (menit) \\
\hline A & 40 \\
\hline B & 42 \\
\hline C & 45 \\
\hline D & 39,8 \\
\hline E & 43 \\
\hline F & 38 \\
\hline G & 40,5 \\
\hline H & 42,7 \\
\hline I & 39 \\
\hline J & 38,5 \\
\hline & \\
\hline
\end{tabular}

Berdasarkan data waktu tempuh yang dicatat oleh panitia lomba pada tabel yang ditunjukkan pada wacana berjudul "Balap Sepeda Motor", rata-rata kecepatan dari sepuluh sepeda motor tersebut adalah ... $\mathrm{m} / \mathrm{s}$ (pembulatan dua angka di belakang koma untuk setiap kecepatan) Jawab:

Gambar 8. Soal Nomor 14 pada Indikator-1

Pada soal nomor 12 dan 14 pada indicator-1 menunjukkan bahwa siswa banyak menjawab salah. Hal ini disebabkan karena pada kedua soal tersebut diberikan wacana yang menginformasikan berbagai macam angka berkaitan dengan matematika dasar dan digunakan untuk menyelesaikan masalah yang diberikan. Pada nomor 13, banyak siswa yang menjawab benar karena informasi yang diberikan berhubungan dengan konsep pengukuran jangka sorong. Seperti soal nomor 4, siswa perlu memahami dan mengingat kembali konsep pengukuran yang telah diberikan. Jika siswa banyak menjawab benar maka retensi siswa dapat dikatakan bagus. Jika retensi siswa bagus maka sebuah konsep tidak akan segera hilang dari ingatan siswa (Nusantari, 2018).

Penelitian ini masih perlu dikembangkan dan dilanjutkan untuk mengetahui jenis pembelajaran yang sesuai dalam peningkatan kemampuan numerasi siswa. Kemampuan numerasi dapat meningkat dengan penerapan pembelajaran yang melibatkan siswa secara aktif untuk menyelesaikan masalah, yaitu model pembelajaran problem solving (Hartatik \& Nafiah, 2020).

\section{Kesimpulan}

Berdasarkan hasil penelitian dan pembahasan, dapat disimpulkan bahwa kemampuan numerasi siswa kelas XI MA Darul Ma'wa Plandirejo kecamatan Plumpang kabupaten Tuban masih rendah. Hasil tersebut dilihat dari analisis ketiga indikator numerasi yang diadopsi. Indikator-1 memberikan hasil terendah dibandingkan dengan ketiga indikator yang lain. Hasil penelitian menunjukkan bahwa 61,90\% siswa mendapatkan nilai di bawah 50 pada tes kemampuan numerasi. Persentase jawaban salah untuk masing-masing indikator 1, 2, dan 3 berturut-turut adalah $64,76 \% ; 48,57 \%$ dan 44,67\%. Pada Indikator-1, siswa banyak memberikan jawaban salah pada soal nomor 12 dan 14 sedangkan siswa banyak memberikan jawaban benar pada soal nomor 13. Pada indikator-2, siswa banyak yang menjawab salah pada soal nomor 7 dan siswa banyak memberikan jawaban benar pada soal nomor 9 . Pada Indikator-3, siswa memberikan jawaban salah pada soal nomor 4 dan banyak memberikan jawaban benar pada soal nomor 8. Penelitian ini masih perlu dikembangkan dan dilakukan penelitian 
lanjutan yang betujuan dalam mengetahui pembelajaran yang sesuai dalam peningkatan kemampuan numerasi siswa.

\section{Daftar Pustaka}

Aisah, H., dkk (2021). Implementasi Kebijakan Asesmen Kemampuan Minimum (AKM): Analisis Implementasi Kebijakan AKM. Jurnal Pendidikan Islam Al-Affan. 1 (2), 128-135.

Andiani, D., dkk. (2020). Analisis Rancangan Asesmen Kompetensi Minimum (AKM) Numerasi Program Merdeka Belajar. Jurnal Matematika dan Pendidikan Matematika (Majamath). 4 (1)

Kusumaryono, R. S. (2020). Merdeka Belajar. Direktorat Jenderal Guru Dan Tenaga Kependidikan Kementerian Pendidikan Dan Kebudayaan. (Online) (https://gtk.kemdikbud.go.id/readnews/merdeka-belajar), diakses 29 April 2021.

Goos, M., dkk. (2011). Improving Numeracy Education in Rural Schools: A Professional Development Approach. Mathematics. Education Research Journal. 23 (2), 129.

Han, W., dkk. (2017). Materi Pendukung Literasi Numerasi. Jakarta: Kementrian Pendidikan dan Kebudayaan.

Hartatik, S. \& Nafiah. (2020). Kemampuan Numerasi Mahasiswa Pendidikan Profesi Guru Sekolah Dasar dalam Menyelesaikan Masalah Matematika. Education and Human Development Journal. 5 (1), $32-42$.

Maryuliana, S. I. M. I. \& Haviana, S. F. C. (2016). Sistem Informasi Angket Pengukuran Skala Kebutuhan Materi Pembelajaran Tambahan Sebagai Pendukung Pengambilan Keputusan Di Sekolah Menengah Atas Menggunakan Skala Likert. Jurnal Transistor Elektro dan Informatika. 1 (2), $1-12$.

Maulidina, A. P. \& Sri, H. (2019). Profil Kemampuan Numerasi Siswa Sekolah Dasar Berkemampuan Tinggi dalam Memecahkan Masalah Matematika. Jurnal Bidang Pendidikan Dasar (JBPD). 3 (2).

Nusantari, E. (2018). Kajian Faktor Yang Mempengaruhi Retensi Siswa SMA (Analisis Hasil Penelitian Eksperimen dan PTK). Prosiding Seminar Nasional Universitas Gorontalo.

OECD. (2018). Survey International Program for International Student Assessment (PISA). (Online) (http://www.oecd.org/pisa), diakses 17 Februari 2021.

OECD. (2014). PISA 2014 Results: What Students Know and Can Do StudentPerformance in Mathematics, Reading and Science. Volume I. Paris: OECD Publishing.

Pangesti, F. T. P. (2018). Menumbuhkembangkan Literasi Numerasi pada Pembelajaran Matematika dengan Soal HOTS. Indonesia Digital Journal of Mathematics and Education. 5 (9).

Pusmenjar Kemdikbud. (2020). Asesmen Kompetensi Minimum. (Online) (https://www.youtube.com/watch?v=ukNxwCtGzZU), diakses 12 Maret 2021.

Wicaksana, Y., dkk. (2017). Analisis Kemampuan Literasi Matematika dan Karakter Rasa Ingin Tahu Siswa pada Pembelajaran Berbasis Proyek Berbantuan Schoology. Unnes Journal of Mathematics Education Research. 6 (2), 167-174.

Yuanita, \& Kurnia, F. (2019). Analisis STEM (Science, Technology, Engenering And Mathematicss) Materi Kelistrikan pada Buku Tematik Tema 3 Kelas 6 Sekolah Dasar. Prosiding Simposium Nasional Multidisiplin (SinaMu) tabun 2019. 